ks. Andrzej Proniewski

Uniwersytet w Bialymstoku

DOI: $10.15290 /$ std.2016.02.11

\title{
MARITAL PARENTHOOD PLANNING
}

\section{MAtŻEŃSKIE PLANOWANIE RODZICIELSTWA}

Sakramentalny związek małżeński w swojej istocie ukierunkowany jest na prokreację. Jest ona owocem miłości dwojga małżonków. Odpowiedzialne rodzicielstwo jest zakorzenione w integralnej wizji małżeństwa, w której seksualność nie jest tylko źródłem przyjemności ale jest włączona w służbę miłości i życia. Podjęta w artykule problematyka ukazuje potrzebę planowania rodzicielstwa, stąd jego logiczna struktura zawiera takie zagadnienia jak: semantyka pojęcia planowane rodzicielstwo (1), ewolucja działań podejmowanych w Kościele na rzecz planowanego rodzicielstwa (2), ukazanie podstaw teologiczno-antropologicznych (3), potrzeba odpowiedzialności małżonków w związku sakramentalnym (4) i rodzicielstwo w miłości (5).

Słowa kluczowe: sakramentalne małżeństwo, miłość małżeńska, planowanie rodzicielstwa, odpowiedzialne rodzicielstwo.

Planning is a dynamic concept that is mobilizing to create the particular circumstances of the human person life. The woman and the man before the conclusion of the sacramental relationship plan their marriage. Planned activities are thought-out initiatives. Issues concerning planning are shaped on the basis of the predisposed person. Some are able to plan and mobilize themselves to implement plans, for others it is with greater difficulty. You act without planning, and suffer the consequences of a situation created spontaneously. The planned marriage is a better way for planned parenthood than the one that makes the affianced couple to be parents first and then inspires them to marry. Such an approach, especially in the long-term actions do not always produce the appropriate results. It is better, therefore, when both women and 
men learn creative engagement and planning of their activities, not only in the economic or political life but also emotional, sexual or procreative.

\section{Meaning of the concept}

Planning as a characteristic of positive thinking applies not only to the creation of structures of ordering various fields of human life. It covers the operation of the basic cell of society, the original social microstructure, which is the family. ${ }^{1}$

Planning parenthood and, consequently, the family is a vividly interpreted issue in modern societies for the family as a dynamic and developmental institution is the basis of their existence. However, there are big differences in the interpretation of the nature and functioning of the family, due to ideological assumptions, new opportunities resulting from advances in biology and medicine, as well as personal attitudes relating to the phenomenon of life which affect the understanding of family planning.

In the Dictionary of marriage and the family, the concept of family planning is defined as "desired number of children and the spacing between pregnancies (ie. conceiving another child) in the family, and the number of children in all families of the society"2. The author explains that "spouses as people gifted with free will and reason, according to the task, arising from the nature of marriage, have the right to engage in sexual relations both in the fertile and infertile periods, as well as the right to periodically resign from sex [... ] depending on the planning or postponing the moment of conception." ${ }^{3}$ The author continues, "this attitude is the most correct, provided that there is the attitude of openness to every unborn child and the potential of parenthood, implemented in a responsible and generous way." ${ }^{4}$ The above argument is reduced to taking into account the possibility of conception of children in the family in the context of their rational planning of maintaining an open attitude towards every conceived life. This action is based on the personalistic vision of man, which refers to the person as a corporeal and spiritual being, endowed with the ability to make free decision and a choice.

Action in freedom as in the case of selecting a spouse, care for the development and maturation in love, as well as the creation of a seed, brings

$1 \quad$ H. Podedworna, Analiza struktur społecznych. Wybrane przykłady, [in:] J. Polakowska-Kujawa (ed.), Socjologia ogólna. Wybrane problemy, Warszawa 1999, p. 105-119.

2 Z. Szymański, Planowanie rodziny, [in:] E. Ozorowski (ed.), Słownik małżeństwa i rodziny, Warszawa - Łomianki 1999, p.334.

3 Z. Szymański, Planowanie rodziny, op. cit., p. 335.

4 Ibidem. 
the consequences of the individual and social nature. Personal, because two spouses shapes their attitude of responsible parents through proper education of children, which allows to develop educational predispositions, potentially encoded in spouses. Social, because through the family is made the correct, natural development of society.

Mature decision on parenting and responsible conception cannot be understood without taking into account properly interpreted the term of family planning. ${ }^{5}$ It should therefore be noted that family planning is a concept, the scope of which relates to the foresight and determination of the intended number of children and the time of their conception, however, does not apply to methods of implementation of the plan. Therefore, the determination of the total, so morally proper fertility planning, and the choice morally legitimate planning methods, adopted a different term natural family planning ${ }^{6}$. Natural family planning means acting, eliminating from family planning, contraception and abortion. The cause of this confusion is treating contraceptive methods as well as natural family planning methods as morally equivalent, as aiming for the same purpose. ${ }^{7}$ It is common to use a convertible term responsible parenthood. Also, the term birth control is wrong, because this name does not exclude abortion and contraception. It would be better to use the term planning conception. ${ }^{8}$ Proponents of such a recognition of the case as contraceptive

5 Application of the term family planning made in the context of utilitarianism these movements and organizations that included methods contraception, abortion and sterilization of people to family planning. Family planning based on the use of contraceptive methods has been called by the International Planned Parenthood Federation - IPPF International Planned Parenthood Federation, as planned parenthood. Cf. W. B. Skrzydlewski, Planowanie rodziny - wyzwanie moralne, Kraków 1998, p. 12-18.

6 Natural family planning is based on the natural rhythm of fertility. It indicates a married couple fertile and infertile days in a woman's cycle, based on indicators of fertility, so those that each woman is able to observe at home. In measuring core body temperature, or observation of mucous and examination of the cervix. The behavior of such a procedure should contribute to avoid speaking colloquially, unwanted pregnancy, or planning a desired child. The second aspect - the planned conception - there are very few accepted this notion, and yet it is particularly important. In the natural family planning in terms of awareness of their own fertility and the possibility of its management, increasing the time interval between children and application of knowledge about the states increased fertility purpose of conceiving a child. Cf. M. Szczawińska, Naturalne planowanie rodziny a antykoncepcja, [in:] E. Burzyk (ed.), Odpowiedzialni za życie i mitość, Bielsko-Biała 1996, p. 87.

7 Such an approach to the problem suggested Bernhard Haring, famous Catholic moralist. But this is the wrong concept.

8 Cf. W. B. Skrzydlewski, Planowanie rodziny - wyzwanie moralne, op. cit., p.16. 
methods include the natural family planning, which causes quite a stir among people and organizations dealing with issues of family planning.

Contraception is the attitude and consequent behavior, precluding the creation of a new human life through sexual relations, and so negatively oriented to human life. In contrast, natural family planning is the attitude and behavior, positively geared to a new life in the family, because their job is mainly to set a deadline of conception. It does not preclude the adoption of a new human life, when it appears as a result of a sexual relationship, which was not intended by spouses to appear in the family. Contraceptive methods and methods of natural family planning 9 are not so equivalent methods, leading to the same goal, because some are geared to the new human life negatively and one positively, some rule out new life, and the other admit it.

\section{Evolution of activities}

Spouses living in the sacramental relationship, in planning parenthood apply the alternative of two currents regulating procreation: natural and ecological mainstream, based on respect for the biological rhythm of fertility and infertility of human pair and contraceptive current - nonecological, destroying the same procreative ability or its fruits in the form of already conceived child. Thus, methods or agents belonging to one or the other mainstream control procreative functions, but are fundamentally different in the way of achieving the goal.

The Church has consistently rejected all abortions and contraceptives as a source for planning parenthood. For a period of time the whole of Christianity in this respect was uniform. Only conference of Anglican bishops in Lambeth in 1930 announced a declaration in which they said that under certain conditions it is justified to use contraceptives. In the wake of the Anglican episcopate declared the Protestant churches, which appealed to the difficulties experienced by many families in view of the rapidly increasing population density around the globe.

In response to this declaration, Pius XI issued the encyclical about christian marriage Castii connubi (December 31,1930$)^{10}$. In this document, the Pope

$9 \quad$ Natural family planning is focused on explaining natural methods based on regular intervals of fertility so-called "diary" in Ogino-Knaus method and natural symptomatic methods: Billings' ovulatory, dr. Kramarek's thermal, Krömer's sympto-thermal or dr. Massalska's multisignal. Cf. W. B. Skrzydlewski, Planowanie rodziny - wyzwanie moralne, op. cit., p. 151-153.

10 Cf. P. Barbieri, D. Tettamanzi (ed.), Matrimonio e famiglia nel magistero della Chiesa, Milano 1986. 
made it clear that all marital intercourse, which is deliberately deprived by a man of its natural reproductive power, breaks the law of God and the natural and stains those who commit such a thing with grave fault. The position taken by the Holy See in this important case coincided with the publication of new scientific achievements solving the problem of birth control in the natural way. The author of this research was Kyusaku Ogino, and they concerned the regularity of periods of fertility commonly called "diary". In the wake of these developments in the late 40s introduced the thermal test, which was a new stage in the development of natural methods of birth control.

Pope John XXIII in his encyclical Mater et Magistra (May 15, 1961) pointed the rules to solve the demographic problem. It is located in economic development and social progress, respecting the true human values, individual and social, implemented in accordance with morality, in a manner worthy of man and the value that is human life ${ }^{11}$. "We must solemnly proclaim that human life is transmitted by means of the family, and the family is based upon a marriage which is one and indissoluble and, with respect to Christians, raised to the dignity of a sacrament. The transmission of human life is the result of a personal and conscious act, and, as such, is subject to the all-holy, inviolable and immutable laws of God, which no man may ignore or disobey. He is not therefore permitted to use certain ways and means which are allowable in the propagation of plant and animal life.

Human life is sacred - all men must recognize that fact. From its very inception it reveals the creating hand of God. Those who violate His laws not only offend the divine majesty and degrade themselves and humanity, they also sap the vitality of the political community of which they are members."(MEM 3).

In the sixties technological revolution increasingly decoupled human from necessity to subject to natural mechanisms. This independence, in itself positive, has created the temptation of disregarding the order of nature, with its natural aims. The impact of scientific and technological revolution marked also in the field of sexuality, bringing new solutions of hormonal contraceptive tablet (pills) and intrauterine device (spiral) ${ }^{12}$. In the face of new signs of the times, Pope Paul VI signed the encyclical Humanae vitae (July 25, 1968).

In the encyclical, Paul VI outlined an integral vision of man and characterized conjugal love as a feeling involving sensual and the spiritual realm of experience of the human person. He stressed at the same time, it is faithful,

11 Cf. E. Ryszka, A. L. Szafrański, Teologiczne i personalistyczne zasady planowania rodziny $i$ regulacji poczęć, [in:] A. L. Szafrański (ed.), Małżeństwo i rodzina w świetle nauki Kościoła $i$ wspótczesnej teologii, Lublin 1985, p. 309.

12 Cf. W. Fijałkowski, Wplyw encykliki Humanae vitae na rozwój naturalnego planowania rodziny, „Życie katolickie” 7 (1988), p. 37-38. 
exclusive and fruitful love ${ }^{13}$. It is not exhausted, therefore, in the community of spouses, but tends toward its extension and giving new life. The encyclical mentioned about the interior order and characterized the dual function of the sign in the sexual act in marriage ${ }^{14}$.

At the congress in Cali they accepted formula for determining what is natural family planning: "These are methods based on the observing in the intercourse the cyclically occurring periods of fertility and infertility. To avoid pregnancy do not come into the picture hormonal, chemical or mechanical methods, or surgery, but only periodical refraining from sexual intercourse during cyclic fertility. Intercourse, if any, remains an intact act ${ }^{15}$. "Eight years later R. Cremins gave the definition: "Natural family planning is the freedom of choice a way of life by marrying deciding on granting or not granting intention of conceiving a child by periodically making intercourse according to the cyclic phases of fertility or infertility, while the act of sex remains intact. It does not apply to anything which would render that act from natural fertility or unable implantation of the embryo. Spouses determine time of fertility on the basis of symptoms appearing from time to time in the cycle" 16 .

Conciliar teaching on marriage and family promotion is contained primarily in the Dogmatic Constitution on the Church Lumen Gentium and the Pastoral Constitution on the Church in the Modern World Gaudium et Spes. Lumen gentium requires from all secular an honorable duty to contribute to the development of the plan of salvation. At the same time it remains in this document emphasized that in the proclamation of the faith and in the witness of love for the laity especially valuable is the state of life, which is sacred with a separate sacrament, namely, married and family life (LG 33, 35).

Gaudium et Spes defines issues of marriage and the family as that which should be the subject of universal concern (GS 46). In this document, the understanding of happiness of the human person and the whole of human

13 Cf. J. Bajda, Humanae Vitae: Encyklika na nowo odczytana, „Studia nad Rodziną UKSW 2 (2002)”, p. 69-115; A. Derdziuk, Człowiek - mitość - rodzina. „Humanae Vitae” po 30 latach, „Ethos” 12 (1999), p. 439-445; L. Gormally, „Humanae Vitae” po 25 latach: w jakim miejscu zastat nas czas obecny?, „Znak” 8 (1995), p. 53-69.

14 Cf. P. P. Ogórek, Refleksja teologiczno-moralna z okazji 30-lecia encykliki Humanae Vitae, „Studia Theologhiae Varsoviensis” 2 (1998), p. 51-69.

15 W. Fijałkowski, Sprawozdanie z I Światowego Kongresu Międzynarodowego Towarzystwa Rozwoju Życia w Rodzinie (International Federation for Family Life Promotion - IFFLP, 22-29 VI Cali - Columbia), „Ginekologia Polska” 49 (1978), p. 153.

16 W. Fijałkowski, Wplyw encykliki Humanae vitae na rozwój naturalnego planowania rodziny, op. cit., p. 42. Also E. Skowrońska, Naturalne planowanie rodziny jako alternatywa antykoncepcji, „Ełckie Studia Teologiczne” 1 (2000), p. 287-296. 
society is linked closely to the prosperity of conjugal and family. Attention is paid to the fact that today there are many factors diminishing the dignity of marriage and the family. These include polygamy, the plague of divorce, free love and other forms of distortion. Conjugal love, and thus the family, within the meaning of the conciliar teaching is reduced by selfishness, hedonism and illegal procedures against conception (GS 47).

Gaudium et spes provides the justification of great dignity of marriage and the family, its vocation and holiness. Marriage and the family, as an intimate communion of life and love, is established by the Creator and governed according to his rights. Hence this relationship, both for the sake of marriage and offspring, and society cannot be dependent on human judgment or conditioned by only human rights. Multiform love realizing in the marriage and the family was, as highlights the document, generously blessed by the Redeemer Jesus Christ (GS 48). This subordination of marriage and the family to the plan of the Creator and his law is manifested above all in the delicate issue of marital fertility and respect for life. Christian couples cannot act in this matter according to their own whim, but should always be guided by conscience adapted to the law of God, which is interpreted by the Magisterium of the Church (GS 50, 51).

Then there is the document of exhortation Familiaris consortio, which was based on the Synod of Bishops dealing with the problems of the family. It took place in Rome in the autumn 1980 (September 26 to November 25). As John Paul II stated at the beginning of the exhortation, the synod has become a sign of profound interest of the Church about family in the contemporary era ${ }^{17}$.

The analyzed texts of Familiaris consortio reveal marriage issues in the deeply human context. The problem of interpersonal relationships, understanding of human sexuality, faithful love, are not after all only theological problems, but above all deeply human. Therefore, in consideration of the marriage and family we should enter the entire anthropological issues, or issues concerning the understanding of the nature and vocation of man the person as a substantially-spiritual being. In this way Familiaris consortio fits firmly in the consolidation of the traditional and consistent with human nature family model. The beginning of the family is marriage between a man and a woman. Thus there is a profound justification for the faithful love of

17 Cf. R. Sztychmiler, Obowiazki matzeńskie wedtug adhortacji apostolskiej Familiaris Consortio i innych okołokodeksowych dokumentów kościoła, „Studia Warmińskie” 34 (1997), p. 329-337. 
the spouses becomes a foundation for understanding of the proper vocation of the family. It is important to prepare spouses for marriage ${ }^{18}$.

Responsibilities of spouses in the context of family planning have also been expressed in the Charter of Rights of the Family published by the Holy See on 22 October $1983^{19}$.

The problem of life is at the heart of what we call together with John Paul II civilization of love. In the Letter to the families Gratissimam sanae, published on the occasion of Year of the Family, John Paul II insisted that the family is the basis of what Pope Paul VI called the civilization of love. According to the mind of the Holy Father civilization of love ${ }^{20}$ is opposed to the mentality of the usage, consumption, as well as the associated pro abortion trends and inadequate birth control. "The civilization of love means joy - among other things, that a man is born into the world" (LDR 13).

Pope Francis in the apostolic exhortation Amoris laetitia supports this interpretation of life and explains, he wrote: "Every child growing within the mother's womb is part of the eternal loving plan of God the Father [...] Each child has a place in God's heart from all eternity; once he or she is conceived, the Creator's eternal dream comes true. Let us pause to think of the great value of that embryo from the moment of conception. We need to see it with the eyes of God, who always looks beyond mere appearances." ${ }^{21}$

\section{Theological and anthropological fundamentals}

The man realizes that he is called to a dynamic, individual development. Conceived by a man and a woman develops, and upon reaching maturity he is planning a new family community. The environment in which man lives and develops in a family, based on the sexual differentiation of men and women who joining in marriage are planning a family.

John Paul II formulated two arguments concerning the foundation of family planning: theological and anthropological one. In theological he pointed out that deciding on the use of contraception, married couples want to have procreative power alone, although given the power of God to perform it only with God as his co-workers. Using contraception, spouses deprive themselves

18 Cf. M. Szymonik, Dwadzieścia lat adhortacji Jana Pawła II o zadaniach rodziny chrześcijańskiejw świecie wspótczesnym „Familiaris Consortio”, „Sosnowieckie Studia Teologiczne” 6 (2003), p. 259-271. Holy See, Charter of Family Rights, „Communicationes” 15 (1983), p. 140-152.

The first chapter of Letter to Families was entitled Civilisation of love. Cf. John Paul II, Letter to Families, Città del Vaticano 1994, 12-68.

Francis, Apostolic exhortation Amoris laetitia, Wrocław 2016, 136. 
of this power and invade the powers of God, pretending to obtain belonging exclusively to him the right to decide about human life. As a result, they are no longer cooperate with God, but self-proclaimed masters of human life.

The anthropological argument recalled that the sex act of married expresses the total reciprocal gift of themselves by spouses. Who use contraception is deprived of the procreative power, and therefore does not give fully her femininity or his masculinity to the spouse. ${ }^{22}$ She refuses him something of herself. This is contrary to one's total gift of self and the overall character of love. Who uses contraception, deprive yourself and your spouse of specific possibilities of being a father or mother and the opportunities for personal development by experienced while being a parent. The denial of this possibility is contrary to conjugal love and with the requirements of the sacrament of marriage, which requires spouses to help each other in achieving salvation as much as possible in the personal development.

In the modern world distorts or entirely misinterprets the true meaning of sexuality, depriving it of a reference to the person. In this, so the social and cultural reality the Church presents sexuality as a value and at the same time the task of the whole person, created by God in his image and likeness. Pope John Paul II in Familiaris consortio, also uses the personalistic argument "Couples, by means of contraception act as "arbiters" of the divine plan and they "manipulate" and degrade human sexuality-and with it themselves and their married partner-by altering its value of "total" self-giving. Thus the innate language that expresses the total reciprocal self-giving of husband and wife is overlaid, through contraception, by an objectively contradictory language, namely, that of not giving oneself totally to the other. This leads not only to a positive refusal to be open to life but also to a falsification of the inner truth of conjugal love, which is called upon to give itself in personal totality." (FC 32).

All contraceptives change human nature, directly affecting physiological processes occurring in the body. Artificially caused infertility is an abnormal state, having a negative impact on the health and well-being. Fertility is a symptom and the medium maintaining mental balance of man and woman.

John Paul II very accurately showed the anthropological and moral difference between contraception and the rhythm of the cycle in Familiaris consortio: "The choice of the natural rhythms involves accepting the cycle of the person, that is the woman, and thereby accepting dialogue, reciprocal respect, shared responsibility and self-control. To accept the cycle and to enter into dialogue means to recognize both the spiritual and corporal character of conjugal communion and to live personal love with its requirement of fidelity.

22 Cf. A. Pryba, Planowanie rodziny jako wewnętrzny aspekt odpowiedzialnego rodzicielstwa. „Teologiczne Studia Pelplińskie” 33 (2002), p. 525-538. 
In this context the couple comes to experience how conjugal communion is enriched with those values of tenderness and affection which constitute the inner soul of human sexuality, in its physical dimension also. In this way sexuality is respected and promoted in its truly and fully human dimension, and is never "used" as an "object" that, by breaking the personal unity of soul and body, strikes at God's creation itself at the level of the deepest interaction of nature and person."(FC 32).

Sexual intercourse strenghtens love ${ }^{23}$, but it does not exhaust it; It can be a source of joy, but also a common and voluntary resignation from it is a factor supporting the mutual love and giving much higher joy. This also applies to the resignation of the period of fertility, if voluntarily and generously made ${ }^{24}$. Spouses must learn so much needed abstinence ${ }^{25}$.

The attitude in defense of man, his sexuality, freedom and marriage is built on the basis of the theological and anthropological principles such as faith in God, faithfulness to the covenant and the dignity of life.

Faith in God and in his revelation and presence on the ground reinforces in man the belief of God's guidance the life of every human being. Marriage is a covenant, "a communion between God and men" (FC12), a community of love and as such is expressed, among others, respecting the dignity of the spouses, who never should treat each other as a means to achieve a unilateral advantage, and therefore as an object ${ }^{26}$. Hence conjugal life, expressing mutual love, is conditioned by common accord with the right of each party to fully experience combined with the awareness of the gift of folding the other side, and which is realized in full satisfaction of sensual and spiritual; selfish attitude is a sin against love and fidelity sworn at the altar.

Human life is a being whose ontological property is dignity, recognized in relation to God and the world. It is entitled to a man in a sustainable, essential and obligatory way. Man is a person that makes he has the highest perfection of living among the other creatures. This is due to the human dignity of the spouses they take lifestyle based on naturally planned parenthood, in which each child and other people are the best for each other. The basic human right is the right to life, which is sacred because from its beginning it involves the creative action of God and it remains forever in a special relationship

23 Pontificio Consiglio per la Famiglia, Sessualità umana: verità e significato, Milano 1996.

24 A. Cappella, Corso di anatomia e fisiologia della riproduzione umana, Roma 2000.

25 Cf. C. Caffarra, La castità coniugale, [in:] S. Oddi (ed.), La procreazione responsabile. Fondamenti filosofici, scientifici, teologici, Roma 1992, p. 173-184

26 Description concerning the analysis of marriage as a covenant with God we find [in:] Cz. Rychlicki, Sakramentalny charakter przymierza matżeńskiego, Płock 1997. 
with the Creator, who is its sole end. "God alone is the Lord of life from its beginning until its end" (EV 53). Sanctity of life, the dignity of the human person is a part of the order of creation ${ }^{27}$. This applies to all of life, including the handicapped. The parents, who live according to the principles of natural family planning, that is, the principles of the Gospel, take each child and also that handicapped; They do not think about the destruction of him - precisely because of his dignity.

The dignity of human life is its superiority over animals and its proximity to life of God. God has given man "in him only competent spiritual powers, such as reason, discernment between good and evil, free will. (...) Among all visible creatures only man is capable of knowing and loving his Creator. Only the man is able to know himself, his body, only a person can see and read the laws of nature governing human fertility in the spirit of responsible parenthood. Natural family planning is a reading plan of the Creator inherent in the natural order of human fertility.

A conceived new life, "a living reflection of their love, a permanent sign of conjugal unity and a living and inseparable synthesis of their being a father and a mother." (FC 14) As an "event" in the history of salvation provided by God before the foundation of the world and called from nothingness by the interaction of parents for glory of the Creator, should be accepted and adopted with love, even the one in this case against the plans for a family. Every child has the right to integral development and education.

\section{Responsibility of spouses}

The right approach to family planning depends on an adequate and mature attitude of spouses ${ }^{28}$. Their attitudes vary in this area widely, depending largely on information on family planning, information is often partial or even erroneous. There are primitive attitude when the spouses do not want to take care of family planning and aim in advance to accept any number of children that occur as a result of their sex life. This is often religiously motivated, when spouses want to accept "what God gives." Sometimes, however, this attitude stems from laziness or irresponsibility. The consequence of such attitudes is sometimes the most excessive fertility of spouses actualizing in too frequent pregnancies and births, which reflected negatively on the health of a mother and children and cause serious economic and educational difficulties.

27 Cf. A. Scola, Implicazioni antropologiche di una catechesi matrimoniale e prematrimoniale, [in:] S. Oddi (ed.), La procreazione..., op. cit., p. 197-213.

28 Cf. A. R. Luño, Spontaneità, amore e castità coniugale, in: S. Oddi (ed.), La procreazione..., op. cit., p. 185-196. 
The most common phenomenon today are attitudes theoretically accepting the idea of family planning, but rejecting the principles of natural planning and reduced to the use of contraception, as seemingly easier and giving any freedom to take your sex life. The result of such attitudes is disappearance of the spirit of generosity in spouses and spreading the atmosphere of selfishness, and sometimes also resort to abortion when used contraceptive methods fail.

The ideal attitude takes place when the spouses generously and responsibly take and implement the principles of natural family planning, taking into account the requirements of his parental vocation and social development and taking into account the consequent health, housing, economic, demographic and educational conditions ${ }^{29}$.

Theology of conjugal love is based on the model viewed in God and concrete in Christ's love for the Church. Responsible parenthood is rooted in the integral vision of marriage, in which sexuality is not only a source of pleasure, but it is always turned on in the service of love and life. Spouses guided by this principle should know the natural method of birth control and in accordance with their conscience, formed on the basis of the doctrine of the Church, must make decisions about the time and the number of children. Adjusting the conception consistent with the ethical principles concerns not only the methods of making. It is based on rational mastery over impulses and openness to the will of the Creator. The use of natural methods is not about the same technique and obedience to the law, but about personal expression of dialogue with God, through which a man turns his obedience to Him.

Responsible parenthood is associated with the objective moral order established by God, which fine interpreter is true conscience. Spouses should be aware of their duties toward God, themselves, their families and the society to which they belong, while maintaining the objective hierarchy of values. In giving life they cannot act on their own and independently, but must adapt to and known by faith the plan of the Creator, contained in the very nature of marriage and its features, and commented in the ordinary teaching of the Church, which Christ promised and constantly sends his Spirit of Truth (HV 10).

Responsible parenthood combines organically with the purity of marriage, flowing from God's love and transforming the natural forces in the sacrificial ability to serve the family. Purity brings harmony, peace, upholds respect for the spouse, it helps to overcome selfishness, the opposite of genuine love, strengthens the sense of mutual responsibility and underpins the educational

29 Cf. E. Skowrońska, Naturalne planowanie rodziny..., op. cit., p. 290. 
influence on children strenghten in them respect for the true human values (HV 21).

Family planning is the responsibility of every married couple. The complexity of the problem, however, and its numerous conditions require psychological, religious, moral and social maturity of spouses. The most important factor is properly formed conscience, and constantly developing on the basis of the teachings of the gospel and the Church. Indispensable is also full confidence to the Creator, who demands people, sometimes very highly, serves them his help to enable them to overcome all the difficulties piled on their way of life.

\section{Planning parenthood in love}

Very important, though usually unexpected, result of natural family planning is to increase the love between spouses. Conjugal love is to be human, full, faithful, exclusive and fruitful. This excludes the violation of the separation of the intercourse from marriage and the separation of the conjugal act from openness to the children. Intercourse should be a sign of union of persons intended by God ${ }^{30}$.

Even the most spontaneous and genuine love need to develop. Love, the spiritual dynamic efficiency increases by the respective acts that are updating $\mathrm{it}^{31}$. These actions express love through the gift of myself, the one who loves to the loved one, to be happy. Generosity expressing the gift of self, makes love grows and moves loving to increasing the availability and personal effort.

Natural family planning is based on the generosity implemented in love with love - for sacrificial behavior of periodic abstinence resulting from the knowledge of variable periods of women fertility. This requires renouncing sex life at a time when it could lead to unwanted pregnancy, so it requires a certain sacrifice. This generosity comes from love, and at the same time it increases, because love is growing just by generosity. Therefore, in the couple using NFP parenting and behaving in this periodic abstinence show an increase of love, which makes their relationship has increasingly deeper mutual respect and increasing delicacy and care that the marital sex life would give them as much satisfaction. Only in such an atmosphere of love, respect, understanding and satisfaction growing between spouses, you can grow personally, living responsible parenthood, targeting on mature education of children.

30 Every act of conjugal love is integral to bestow on the part of the spouses to each other, not only on the physical but also mental and spiritual basis. Cf. Congregation for Catholic Education, Wytyczne wychowawcze w odniesieniu do ludzkiej mitości. Zasadnicze cechy wychowania seksualnego, Wrocław 1994.

31 Cf. A. Derdziuk, Człowiek - Miłość - Rodzina..., op. cit., p. 442. 
Key words: sacramental marriage, love, marriage, parenthood planning, responsible parenthood.

\section{Bibliography:}

1. Bajda J., Humanae Vitae: Encyklika na nowo odczytana, „Studia nad Rodziną UKSW" 2 (2002).

2. Barbieri P., Tettamanzi D. (ed.), Matrimonio e famiglia nel magistero della Chiesa, Milano 1986.

3. Caffarra C., La castità coniugale, [in:] S. Oddi (ed.), La procreazione responsabile. Fondamenti filosofici, scientifici, teologici, Roma 1992.

4. Cappella A., Corso di anatomia e fisiologia della riproduzione umana, Roma 2000.

5. Congregation for Catholic Education, Wytyczne wychowawcze w odniesieniu do ludzkiej mitości. Zasadnicze cechy wychowania seksualnego, Wrocław 1994. Derdziuk A., Człowiek - mitość - rodzina. „Humanae Vitae” po 30 latach, „Ethos” 12 (1999).

6. Fijałkowski W., Sprawozdanie z I Światowego Kongresu Międzynarodowego Towarzystwa Rozwoju Życia w Rodzinie (International Federation for Family Life Promotion - IFFLP, 22-29 VI Cali - Columbia), „Ginekologia Polska” 49 (1978).

7. Fijałkowski W., Wplyw encykliki Humanae vitae na rozwój naturalnego planowania rodziny, „Życie katolickie” 7 (1988).

8. Francis, Apostolic exhortation Amoris laetitia, Wrocław 2016.

9. Gormally L., "Humanae Vitae" po 25 latach: w jakim miejscu zastat nas czas obecny?, „Znak” 8 (1995).

10. Holy See, Charter of Family Rights, "Communicationes" 15 (1983).

11. John Paul II, Letter to Families, Città del Vaticano 1994,

12. Luño A. R., Spontaneità, amore e castità coniugale, [in:] S. Oddi (ed.), La procreazione responsabile. Fondamenti filosofici, scientifici, teologici, Roma 1992.

13. Ogórek P. P., Refleksja teologiczno-moralna z okazji 30-lecia encykliki Humanae Vitae, „Studia Theologhiae Varsoviensis” 2 (1998).

14. Podedworna H., Analiza struktur spolecznych. Wybrane przykłady, [in:] J. Polakowska-Kujawa (ed.), Socjologia ogólna. Wybrane problemy, Warszawa 1999.

15. Pontificio Consiglio per la Famiglia, Sessualità umana: verità e significato, Milano 1996.

16. Pryba A., Planowanie rodziny jako wewnętrzny aspekt odpowiedzialnego rodzicielstwa. „Teologiczne Studia Pelplińskie” 33 (2002).

17. Rychlicki Cz., Sakramentalny charakter przymierza matżeńskiego, Płock 1997.

18. Ryszka E., Szafrański A. L., Teologiczne i personalistyczne zasady planowania rodziny i regulacji poczęć, [in:] A. L. Szafrański (ed.), Małżeństwo i rodzina w świetle nauki Kościoła $i$ wspótczesnej teologii, Lublin 1985.

19. Scola A., Implicazioni antropologiche di una catechesi matrimoniale e prematrimoniale, [in:] S. Oddi (ed.), La procreazione responsabile. Fondamenti filosofici, scientifici, teologici, Roma 1992.

20. Skowrońska E., Naturalne planowanie rodziny jako alternatywa antykoncepcji, „Ełckie Studia Teologiczne" 1 (2000).

21. Skrzydlewski W. B., Planowanie rodziny - wyzwanie moralne, Kraków 1998. 
22. Szymański Z., Planowanie rodziny, [in:] E. Ozorowski (ed.), Słownik małżeństwa i rodziny, Warszawa - Łomianki 1999.

23. Szczawińska M., Naturalne planowanie rodziny a antykoncepcja, [in:] E. Burzyk (ed.), Odpowiedzialni za życie i mitość, Bielsko-Biała 1996.

24. Sztychmiler R., Obowiazki matżeńskie wedtug adhortacji apostolskiej Familiaris Consortio i innych okołokodeksowych dokumentów kościoła, „Studia Warmińskie” 34 (1997).

25. Szymonik M., Dwadzieścia lat adhortacji Jana Pawta II o zadaniach rodziny chrześcijańskiej w świecie wspótczesnym „Familiaris Consortio", "Sosnowieckie Studia Teologiczne" 6 (2003). 